\title{
Learners' Belief Changes about Language Learning
}

\author{
Ali Mohammad Fazilatfar \\ Dept. of English Language, Yazd University, Iran \\ E-mail: afazilatfar@yahoo.com \\ Rajabali Rayati Damavandi \\ Dept. of English Language and Literature, University of Mazandaran, Iran \\ E-mail: alirayat@yahoo.com \\ Rezvan Harsij Sani \\ Dept. of English Language, Yazd University, Iran \\ E-mail: rharsij@yahoo.com \\ Javad Kia Heirati (Corresponding author) \\ Dept. of English Language and Literature, University of Mazandaran, Iran \\ E-mail: Javad.kiaheirati@yahoo.com
}

Received: October 24, 2014 Accepted: November 14, 2014 Published: November 21, 2014

doi:10.5296/ijele.v3i1.6654 URL: http://dx.doi.org/10.5296/ijele.v3i1.6654

\begin{abstract}
The present study examines university students' beliefs about language learning. Beliefs have been considered as an important factor affecting the process of language learning. In fact, this paper investigates changes in the learners' beliefs during the course of one semester. Data were gathered through the administration of Horwitz's (1988) BALLI questionnaire. Descriptive statics were applied to precisely analyze the quantitative data. The results of students' responses to the questionnaire items revealed that Iranian university students had a positive attitude regarding learning English in that it can provide an appropriate job conditions for them. One highlighting point in terms of their beliefs change included their attitude toward the difficulty of learning English that, at the end of the term, over half of them held this belief that English is a difficult language in comparison with the beginning of the
\end{abstract}


term, which nearly less than one third of the learners had this sort of belief considering English as a difficult language. The findings seem to alert our teachers to adopt an appropriate approach regarding their students' initial realistic beliefs about language learning to help the learners remove their simplistic beliefs and finally may reach to better results at the end of the term.

Keywords: Learners' beliefs, language learning, belief changes

\section{Introduction}

Beliefs are considered as cognitive entities that guide humans to behave in a community, and they are important factors leading human behavior. Beliefs can help individuals to define and understand the world and themselves; in addition, they are instrumental in defining a task and play a critical role in defining behavior (White, 1999). In fact it is the belief of people that gives direction to their behavior and presents them with the capability to be in contact with other members of the society. According to Abelson (1986), beliefs have novel features and are like possessions. Beliefs seem to have important functions that show how significant they are. These functions are: a) providing meaning, b) helping individuals to identify with other people and form groups and social systems, and c) reducing dissonance and confusion (Pajares, 1992). Beliefs have other functions which refer to the framing and defining tasks and facilitating the memory process (Nepor, 1987).

It seems that not only do beliefs affect social aspect of people's lives, but they also have an impact on educational and learning dimension. As to the significance of beliefs in learning, Wenden (1987) states that student beliefs about language learning can influence their language learning strategies. Cotterall (1995) argues that the beliefs learners hold may either contribute to or impede the development of their potential for autonomy. Breen (2001) presents the fact that in the classroom context, the perceptions and beliefs learners bring with them to the learning situation have been considered as an important and effective factor in the learning process and learners' ultimate success. White (2008) argues that beliefs play a significant role in the learning process and "in terms of language learning, the domains of beliefs which are acknowledged as relevant are the beliefs learners hold about themselves, about language and language learning, and about the contexts in which they participate as language learners and language users" (p.121). With respect to the relationship between beliefs and good language learners, White points to Rubin's (1975) article in which he presents this point that beliefs are really crucial to learners in the sense that those true beliefs held by learners direct them toward how they behave and how they interpret their experiences. Thus, studying learner beliefs one can investigate what specific beliefs a learner has and what sort of improvement can be made regarding teachers' understanding of these beliefs in order to have a better result in the process of language learning and ultimate success.

Beliefs can be examined within different fields of Humanities in various contexts. In this regard, there has been an interest among researchers in the field of second language learning to investigate the role beliefs play in the learning process. This recent interest according to 
Kalaja and Barcelos (2003) is the "result of a shift in focus to learners and their contributions to learning second/foreign languages that originates from an even earlier discussion of what characterizes good language learners, including such traits as motivation, aptitude, personality, cognitive styles, and learning strategies" (p.1). They also mention that beliefs are considered as one area of individual learner differences that affect the processes and outcomes of second/foreign language learning/acquisition. Kalaja and Barcelos state some important aspects of beliefs in which "their significance has been related to: a) mismatches between teachers' and learners' agendas in the classroom; b) students' use of language learning strategies; c) learners' anxiety; and d) autonomous learning" (p.1). In this regard, Horwitz (1999) also mentions that studying beliefs second language learners hold about language learning achieved a significant growth in the past two decades. Language educators are in agreement with the fact that beliefs play a major role in learner's language success (Sakui \& Gaies, 1999). According to Horwitz (1987), "these beliefs have varying degrees of validity and numerous origins, often differing radically from the current opinions of second language scholars; in many cases, the term 'myth' might be a more accurate characterization" (p.119). Some beliefs go back to students' previous experiences as language learners. Other beliefs may be shaped by students' cultural backgrounds. Thus, studying learners' beliefs gives us awareness about which of their beliefs are realistic and helpful so that those beliefs that are simplistic and unrealistic could be revised or even removed to assist learners in the learning process.

In terms of the significance of beliefs and the role they play in the process of learning, it is of value to examine beliefs learners hold about learning and probe how these beliefs are to shape and evolve during a specific period of time. Thus, the present study investigates changes in university students' beliefs about language learning during one semester. In fact, it is aimed to examine whether instruction made by teachers can have impact on learners' probable simplistic beliefs about language learning and may lead to changes in learners' beliefs at the end of the term.

\section{Review of Literature}

Belief studies began with the appearance of cognitive psychology in the 1970s. Abelson (1979) confirms that with new developments in cognitive sciences, researches made an attempt to uncover beliefs. Beliefs and belief systems began to be explored at the beginning of twentieth century, particularly by social psychologists (Thompson, 1992). Therefore, it can be said that beliefs and belief systems can be investigated under the notion of cognition. As to the notion of learners' beliefs, researchers in the field of applied linguistics tried to gain a grasp of beliefs learners have about language learning and they are concerned with this issue since 1980s with the work of researchers like Horwitz (1985). She developed the Beliefs About Language Learning Inventory (student and teacher version of BALLI) and Foreign Language Attitude Survey (FLAS) questionnaires to assess students' opinions on a variety of issues and controversies related to language learning via free-recall protocols and group discussions with both foreign language and ESL learners and teachers. The participants in this study were four groups of 25 language teachers of different cultural backgrounds and 150 first-semester language students at the University of Texas at Austin. Horwitz found that a 
systematic assessment of students' and teachers' beliefs provided by BALLI and FLAS would greatly facilitate learning in foreign language methods course.

In her similar study, Horwitz (1988) explored the beliefs of 241 first-semester foreign language learners of German, French, and Spanish at the University of Texas at Austin. In order to investigate learners' beliefs, BALLI questionnaire was used. BALLI items consisted of five major areas including: a) difficulty of language learning; b) foreign language aptitude; c) the nature of language learning; d) learning and communication strategies; and e) motivations and expectations. She found that learners possess some beliefs that have negative effects and are detrimental to successful language learning. For instance, some students believe that it is possible to become fluent in second language in two years or less, and some of them hold this belief that learning a language is a matter of translation from English. Beliefs like these result in negative outcomes for many language learners. Horwitz suggests that for learners in order to be successful, they need to adopt a holistic approach rather than restricting themselves to translation, vocabulary memorization or grammar application.

There are some studies in the area of beliefs which examined the relationships between beliefs and personality traits. For instance, Cotteral (1995) made an attempt to investigate learners' beliefs and its relationship to autonomy. In doing so, she constructed a structured questionnaire which its items were developed from a series of focused interviews. The questionnaire was administered to a group of 139 adult ESL learners. In order to analyze the questionnaire items, factor analysis was used to explain the covariation among responses. She found that students showed more control over their language learning and more use of metacognitive strategies when they are involved in distance learning context. Her findings showed that receiving a new style of learning, new perceptions of language learning will occur.

Similarly, Bernat \& Lloyd (2007) made an attempt to explore the relationship between beliefs about language learning and gender. They constructed BALLI questionnaire to gain a grasp of learners. The Wilcoxon-Mann-Whitney test was employed to investigate gender difference. The study was conducted with the participation of 155 female and 107 male English as a Foreign Language students enrolled in an Academic English Program. Their findings indicated that overall males and females held similar beliefs about language learning, with only one item being statistically significant and another one being marginally significant. In fact this study was in comparison with the study done by Siebert (2003). Overall, the gender differences found in the study differ from those reported by Siebert (2003), using a U.S. sample, in terms of quantity and nature in the sense that this study found two gender differences regarding the relationship between speaking more than one language and intelligence that females being more likely to view that intelligence plays a greater role in language learning than males, and the degree of enjoyment both males and females reported in practicing English with native speakers, with males being more likely to enjoy the experience than females, while in Siebert's study he found eight items with gender differences. 
Researchers made their attempts to probe changes in beliefs with study conducted by Kern (1995) in which he explored changes in student beliefs. The participants included 180 students studying first-year French at a university in the U.S. He reported the changes over the course of one semester (15 weeks). Kern administered BALLI questionnaire during the first and last week of the semester. He found that $35 \%$ to $59 \%$ of the responses changed over the 15 -week period. His findings revealed that many students had become aware of their wrong beliefs and were having difficulty in avoiding them.

Likewise, Peng (2011) investigated the change in one first-year college student's beliefs about language teaching and learning since his enrollment. Semi-structured interviews, classroom observations, and learning journals were used to collect the data over a period of seven months. The findings indicated substantive changes in the student's belief during the transition from high school to tertiary language classrooms which is a critical period, during which learners' beliefs about second language learning are subject to contextual mediation. The findings also demonstrated that beliefs are emergent and context-responsive, in the sense that beliefs changed variably as the context changed.

Although studies carried out in the area of beliefs cover a wide range of research, there is still a need for more studies in this fledging arena. More importantly, there are few studies on learner beliefs change. Hence, more studies are required to grasp changes in learners' beliefs with respect to the context that students exchange their thoughts and to investigate the complex nature of beliefs about language learning. In terms of the significance of beliefs and the role they play in the process of learning, it is of value to examine beliefs learners hold about learning and probe how these beliefs are to shape and evolve during a specific period of time. Thus, the present study investigates changes in university students' beliefs about language learning during one semester. In fact, it is aimed to examine whether instruction made by teachers can have impact on learners' probable simplistic beliefs about language learning and may lead to changes in learners' beliefs at the end of the term.

\section{Research Questions}

This study answers the following questions:

RQ 1: What do university students believe about language learning?

RQ 2: Do the learners' beliefs change after one semester?

\section{Methodology}

\subsection{Participants}

Iranian university students were invited to participate in this study. A total of 198 students of University of Mazandaran volunteered to participate in this study. Of these, 141 were female and 57 were male. The participants include different faculties: Art, Theology, Law, Engineering, Basic Sciences, and Humanities. They were in their second year of the university (the fourth semester) and all of them have not taken any English course yet. 


\subsection{Instrument}

The survey instrument consisted of 34 items from the "Beliefs About Language Learning Inventory" (BALLI) designed by Horwitz (1988). The BALLI is a widely used instrument (e.g. Kern, 1995; Yang, 1999; Tanaka \& Ellis, 2003) to find out learners' beliefs about language learning in five areas: foreign language aptitude, the difficulty of language learning, the nature of language learning, learning and communication strategies, and Motivations and expectations. Students were given the Persian version of BALLI (see appendix A) with some modifications to fit the context of Iran and were asked to read each item, and to respond using a five-point scale, ranging from 1 (strongly agree) to 5 (strongly disagree). The response options asking for the difficulty of the English language learning (item 4) ranged from very difficult (1) to very easy (5), and the one for the item asking about how long it takes to speak English (item 15) ranged from less than one hour (1) to you can't learn a language in one hour per day (5).

\subsection{Data Analysis}

For data analysis, learners' responses to the items were analyzed both descriptively and inferentially. At first, to have a better view of the distribution of the responses, the BALLI item ratings were turned into three categories of agree $(A)$, neutral $(\mathrm{N})$, and disagree (D) and also difficult, neutral, and easy. Then the frequency of the responses for both time 1 (before the semester) and time 2 (after the semester) was calculated and presented in tables. For question one, the chi-square goodness of fit was applied to examine the significance of the changes in the frequency among the participants' choices in time 1. Later, the frequency gained from time 1 and time 2 was compared to see if any changes took place after passing the course.

\section{Results}

\subsection{Foreign Language Aptitude}

The analysis of the participants' responses show that they seem to have a positive attitude toward people's potential to learn a foreign language. As Table 1 shows, a vast majority of the participants believed that everyone was good at learning a foreign language $(86.9 \%)$ and children have a special aptitude in learning a foreign language $(88.9 \%)$. Most of them $(72.7 \%)$ also concurred that some people are born with a special ability to learn a foreign language. While they agreed with people's special ability for learning a foreign language and with this fact that almost everyone has the ability to learn a foreign language, less than half of them $(41.9 \%)$ stated that Iranians are successful in learning English.

Table 1. Language Learning Aptitude from Times 1 and 2

\begin{tabular}{|c|ccc|c|}
\hline Items & $\mathrm{A}$ & $\mathrm{N}$ & $\mathrm{D}$ & Time \\
\hline \multirow{2}{*}{1} & 88.9 & 8.6 & 2.5 & 1 \\
& 86.9 & 9.6 & 3.5 & 2 \\
\hline
\end{tabular}




\begin{tabular}{|c|c|c|c|c|}
\hline \multirow[t]{2}{*}{2} & 72.7 & 15.2 & 12.1 & 1 \\
\hline & 78.3 & 13.6 & 8.1 & 2 \\
\hline \multirow[t]{2}{*}{6} & 41.9 & 33.3 & 24.7 & 1 \\
\hline & 42.9 & 34.3 & 27.7 & 2 \\
\hline \multirow[t]{2}{*}{10} & 55.1 & 25.3 & 19.7 & 1 \\
\hline & 59.9 & 27.4 & 12.7 & 2 \\
\hline \multirow[t]{2}{*}{11} & 5.6 & 22.2 & 72.2 & 1 \\
\hline & 11.1 & 28.8 & 60.1 & 2 \\
\hline \multirow[t]{2}{*}{16} & 40.9 & 39.9 & 19.2 & 1 \\
\hline & 39.9 & 40.4 & 19.7 & 2 \\
\hline \multirow[t]{2}{*}{19} & 26.8 & 44.4 & 28.8 & 1 \\
\hline & 30.8 & 49.5 & 19.7 & 2 \\
\hline \multirow[t]{2}{*}{30} & 59.1 & 28.3 & 12.6 & 1 \\
\hline & 55.1 & 31.8 & 13.1 & 2 \\
\hline \multirow[t]{2}{*}{33} & 86.9 & 9.6 & 3.5 & 1 \\
\hline & 84.3 & 13.1 & 2.5 & 2 \\
\hline
\end{tabular}

A chi-square goodness of fit was conducted and showed a significant difference in the proportion of participants' responses for all the items related to language learning aptitude $\left(\right.$ item 1: $\chi^{2}(1, \mathrm{n}=198)=276.091, p=.00<.05 ;$ item $2: \chi^{2}(1, \mathrm{n}=198)=138.545, p=.00$ $<.05$; item 6: $\chi^{2}(1, \mathrm{n}=198)=8.758, p=.01<.05 ;$ item $10: \chi^{2}(1, \mathrm{n}=198)=42.939, p=.00$ $<.05$; item 11: $\chi^{2}(1, \mathrm{n}=198)=143, p=.00<.05$; item 16: $\chi^{2}(1, \mathrm{n}=198)=17.848, p=.00$ $<.05$; item 19: $\chi^{2}(1, \mathrm{n}=198)=11.121, p=.00<.05$; item 30: $\chi^{2}(1, \mathrm{n}=198)=66.394, p$ $=.00<.05 ;$ item 33: $\left.\chi^{2}(1, \mathrm{n}=198)=256.455, p=.00<.05\right)$.

In terms of their belief related to language aptitude, the changes in the percentages gained in time 1 and 2 were rather small. As can be seen in Table 1 above, the changes in all the items related to language aptitude were up to 6 percents.

\subsection{The Difficulty of Language Learning}

In terms of the difficulty of language learning, as Table 2 shows, over half of the participants 
took the position that finally they would manage to learn English (58\%) and they could learn English in less than two years (57.6\%), while 16.2 percent considered more than five years' duration for learning English. Some of them (13. 6\%) thought that they would not learn English. Furthermore, they considered that some languages are easier to learn than others. Most of them (75.8\%) agreed with the case of learning some languages, and English seems to be one of them. A very small percentage $(26.8 \%)$ concurred that English is a difficult language. About one third of the participants (36.9\%) agreed with the statement that it is easier to speak than to understand a foreign language. Also, almost half of the participants $(54.5 \%)$ agreed with the ease to read and write.

Table 2. Difficulty of Language Learning from Times 1 and 2

\begin{tabular}{|c|ccc|c|}
\hline Items & $\mathrm{A}$ & $\mathrm{N}$ & $\mathrm{D}$ & Time \\
\hline 3 & 75.8 & 16.2 & 8.1 & 1 \\
& 81.8 & 14.6 & 3.5 & 2 \\
\hline 4 & 26.8 & 45.5 & 27.8 & 1 \\
& 54.5 & 40.4 & 5.1 & 2 \\
\hline 5 & 58.1 & 28.3 & 13.6 & 1 \\
& 57.1 & 29.3 & 13.6 & 2 \\
\hline 15 & 57.6 & 26.3 & 16.2 & 1 \\
& 59.1 & 25.3 & 15.7 & 2 \\
\hline 25 & 36.9 & 38.9 & 24.2 & 1 \\
& 38.4 & 35.9 & 25.8 & 2 \\
\hline 34 & 54.5 & 29.3 & 16.2 & 1 \\
& 54 & 32.3 & 13.6 & 2 \\
\hline \multirow{2}{*}{5} & 54.9 & & 2.6 \\
\hline
\end{tabular}

The chi-square of fit was carried out and showed a significant difference in the proportion of the participants' responses related to language difficulty (item $3: \chi^{2}(1, \mathrm{n}=198)=162.303, p$ $=.00<.05$; item 4: $\chi^{2}(1, \mathrm{n}=198)=13.121, p=.00<.05 ;$ item $5: \chi^{2}(1, \mathrm{n}=198)=60.939, p$ $=.00<.05 ;$ item 15: $\chi^{2}(1, \mathrm{n}=198)=55.394, p=.00<.05 ;$ item $25: \chi^{2}(1, \mathrm{n}=198)=7.485, p$ $=.02<.05 ;$ item $\left.34: \chi^{2}(1, \mathrm{n}=198)=45.212, p=.00<.05\right)$. 
Looking at the percentages in the items about language difficulty, it can be seen that except for item 4 the change was so small that shows the participants' views in this regard did not change to a large extent. As to item 4, which is related to the difficulty of English, after passing the semester the number of participants doubled from 26.8 in time 1 to 54.5 in time 2 . Passing a reading course at university seems to have made them believe that learning English is difficult.

\subsection{The Nature of Language Learning}

Table 3 shows the percentage of the participants' responses related to the nature of language learning. Accordingly, a majority of the participants $(85.9 \%)$ took the position that learning a foreign language is mostly a matter of learning a lot of new vocabulary words, whereas they did not take much credit for learning a lot of grammar rules $(31.8 \%)$. Very few of them $(2.5 \%)$ agreed that learning a lot of new vocabularies was not the most significant part of learning English.

Table 3. The Nature of Language Learning from Times 1 and 2

\begin{tabular}{|c|c|c|c|c|}
\hline Items & A & $\mathrm{N}$ & D & Time \\
\hline \multirow[t]{2}{*}{8} & 43.9 & 35.9 & 34.8 & 1 \\
\hline & 48.9 & 20.2 & 15.7 & 2 \\
\hline \multirow[t]{2}{*}{12} & 67.7 & 17.7 & 14.6 & 1 \\
\hline & 70.7 & 23.2 & 6.1 & 2 \\
\hline \multirow[t]{2}{*}{17} & 85.9 & 11.6 & 2.5 & 1 \\
\hline & 79.8 & 14.6 & 5.6 & 2 \\
\hline \multirow[t]{2}{*}{23} & 31.8 & 30.8 & 37.4 & 1 \\
\hline & 21.7 & 40.7 & 37.9 & 2 \\
\hline \multirow[t]{2}{*}{27} & 64.1 & 26.8 & 9.1 & 1 \\
\hline & 65.7 & 28.8 & 5.6 & 2 \\
\hline \multirow[t]{2}{*}{28} & 56.6 & 32.8 & 10.6 & 1 \\
\hline & 53.5 & 33.3 & 13.1 & 2 \\
\hline
\end{tabular}

Not many participants (43.9\%) concurred with the role of getting to know the second language culture. It is interesting to note that most participants $(64.1 \%)$ confirmed that 
learning English is different from other university subjects. Similarly, most learners thought that learning English in an English-speaking country could be considered as the best way $(67.7 \%)$. In addition, over half of the participants (56.6\%) concurred that knowing how to translate from their L1 to L2 was an important part of learning English.

In this regard, the result of chi-square goodness of fit revealed a significant difference among the alternatives for all the items except for item 23 as the frequency of the responses was somehow equally distributed for this item (see Table 3) (item 8: $\chi^{2}(1, \mathrm{n}=198)=17.303, p$ $=.00<.05 ;$ item 12: $\chi^{2}(1, \mathrm{n}=198)=105.364, p=.00<.05 ;$ item 17: $\chi^{2}(1, \mathrm{n}=198)=$ $248.273, p=.00<.05 ;$ item 23: $\chi^{2}(1, \mathrm{n}=198)=1.485, p=.47>.05 ;$ item $27: \chi^{2}(1, \mathrm{n}=198)$ $=93.848, p=.00<.05 ;$ item $\left.28: \chi^{2}(1, \mathrm{n}=198)=62.758, p=.00<.05\right)$.

No considerable changes are also found in learners' belief regarding the nature of language learning (See Table 3). Similar to the changes in the previous categories, no big differences can be seen here. The changes were up to 4 percent except for item 23 in which still very few participants, about 10 percent, changed their mind about grammar as the most important part in learning English from agreement to neutrality.

\subsection{Learning and Communication Strategies}

The analysis of the items related to learning and communication strategies shows that a vast majority of the participants strongly believed in the role of practice and repetition (98\%) and practice with audio and video devices (81.8\%). Interestingly, no one denied the role of practice and repetition in learning English (Table 4). In the participants 'eye, to speak English seems to be relatively important for Iranians (56.6\%). In the same vein, most of the participants (66.2\%) expressed joy in speaking with native speakers of English. About one third of the participants (36.9\%) expressed fear while speaking English with others, and almost one third (39.9) mentioned if a language learners is allowed to make mistakes in the beginning, it will be hard to get rid of them later on. A majority of the participants agreed with speaking with a perfect accent $(80.3 \%)$ and guessing the meaning of unknown words $(80.3 \%)$. However, a very small percentage of them $(26.8 \%)$ held the view that one should not say anything in English until s/he can say it correctly, although almost half of them (47\%) had a different opinion.

Table 4. Learning and Communication Strategies from Times 1 and 2

\begin{tabular}{|c|ccc|c|}
\hline Items & $\mathrm{A}$ & $\mathrm{N}$ & $\mathrm{D}$ & Time \\
\hline \multirow{2}{*}{7} & 80.3 & 13.1 & 6.6 & 1 \\
& 72.2 & 19.2 & 8.6 & 2 \\
\hline \multirow{2}{*}{9} & 26.8 & 26.3 & 47 & 1 \\
& 20.7 & 30.3 & 49 & 2 \\
\hline
\end{tabular}




\begin{tabular}{|c|rrr|l|}
\hline 13 & 66.2 & 27.3 & 6.6 & 1 \\
& 68.2 & 24.7 & 7.1 & 2 \\
\hline 14 & 80.3 & 15.7 & 4 & 1 \\
& 81.3 & 15.7 & 3 & 2 \\
\hline 18 & 98 & 2 & 0 & 1 \\
& 89.4 & 8.1 & 2.5 & 2 \\
\hline 21 & 36.9 & 27.8 & 35.4 & 1 \\
& 32.3 & 39.4 & 28.3 & 1 \\
\hline 22 & 39.9 & 23.2 & 36.9 & 2 \\
\hline 26 & 35.4 & 31.8 & 32.8 & 1 \\
\hline
\end{tabular}

Accordingly, a chi-square goodness of fit was carried out and there was found a significant difference in the participants' choices for all the items except for item 21 since the responses were relatively equally distributed (see Table 4) (item 7: $\chi^{2}(1, \mathrm{n}=198)=197.848, p=.00$ $<.05$; item 9: $\chi^{2}(1, \mathrm{n}=198)=16.576, p=.00<.05$; item 13: $\chi^{2}(1, \mathrm{n}=198)=108.758, p$ $=.00<.05$; item 14: $\chi^{2}(1, \mathrm{n}=198)=200.576, p=.00>.05$; item 18: $\chi^{2}(1, \mathrm{n}=198)=$ $182.323, p=.00<.05 ;$ item $21: \chi^{2}(1, \mathrm{n}=198)=2.818, p=.24>.05 ;$ item $22: \chi^{2}(1, \mathrm{n}=198)$ $=9.364, p=.00<.05$; item 26: $\left.\chi^{2}(1, \mathrm{n}=198)=214.576, p=.00<.05\right)$.

Still, as Table 4 illustrates, no big changes is observed in the proportion of the participants' responses. The changes in the percentage of the two times were rather small, up to 6 percent.

\subsection{Motivations and Expectations}

A vast majority of the participants agreed with the two statements of items $29(89.4 \%)$ and 31 $(92.9 \%)$ in that they can get more job opportunities and they want to speak English very well. Over half of them also agreed that it is important for Iranians to speak English (56.6\%), that it is important to learn to speak English so as to know English people better (54\%), and that they like to have native speakers as their friends (60.1\%) (Table 5). 
Table 5. Motivations and Expectations from Times 1 and 2

\begin{tabular}{|c|ccc|c|}
\hline Items & $\mathrm{A}$ & $\mathrm{N}$ & $\mathrm{D}$ & Time \\
\hline 20 & 56.6 & 32.3 & 11.1 & 1 \\
& 55.1 & 33.8 & 11.1 & 2 \\
\hline 24 & 54 & 27.3 & 13.7 & 1 \\
& 50 & 28.3 & 21.7 & 2 \\
\hline 29 & 89.4 & 8.5 & 2 & 1 \\
& 83.3 & 11.6 & 5.1 & 2 \\
\hline 31 & 92.9 & 6.1 & 1 & 1 \\
& 86.9 & 10.6 & 2.5 & 1 \\
\hline 32 & 60.1 & 38.9 & 11.6 & 2 \\
\hline
\end{tabular}

There was found a significant difference among the participants' selections according to the result of the chi-square goodness of fit (item 20: $\chi^{2}(1, \mathrm{n}=198)=61.455, p=.00<.05$; item 24: $\chi^{2}(1, \mathrm{n}=198)=40.394, p=.00<.05$; item 29: $\chi^{2}(1, \mathrm{n}=198)=281.303, p=.00<.05$; item $\left.32: \chi^{2}(1, \mathrm{n}=198)=45.364, p=.00<.05\right)$

Finally, there is seen no difference among the proportions of the participants' responses in the two times regarding motivations and expectations about learning English. That is, similar to the previous categories, the changes are up 6 percent.

\section{Discussion}

The aim of this study was to investigate changes in students' beliefs about language learning as a result of passing a reading course during one semester at university. Regarding the first research question which aimed at uncovering learners' initial beliefs about language learning, the results showed that Iranian language learners had optimistic beliefs in terms of learning English as they believed that everyone has the ability to learn how to speak English. This might represent their eagerness to learn English and especially speak the language. Concerning their attitude toward English, a very small percentage $(26.8 \%)$ concurred that English is a difficult language which appears to be a hopeful view of learning English. As to the findings, Learners seemed to have simplistic beliefs about language learning since a majority of the participants $(85 \%)$ considered learning vocabularies as the most important part of learning English. This acknowledges Dornyei's and Ushioda's (2011) claim that “it is 
a peculiar fact of life that most learners will have certain beliefs about language learning and most of these beliefs are likely to be (at least partly) incorrect" (p. 117). On the other hand, about one third of the learners (31.8\%) relied on the role of grammar in learning English that might be a kind of realistic belief of language learning in that over half of the participants did not select grammar as the most important components of language. A vast majority of the participants (98\%) strongly believed in the role of practice and repetition which might go back to their high school period in which their focus was much more on practice and repetition. Another interesting point considering learners' initial beliefs was their motivation in learning English that they agreed that it would lead to having better job conditions. This kind of belief clearly reveals the role of learning English in Iran in which English is considered as an important language the apparently helps to finding a better job. The findings seem to be in agreement with Horwitz's (1988) study in which she found that learners possess some beliefs that have negative effects and are detrimental to successful language learning.

In terms of investigating changes in the learners' beliefs about language learning, the second research question was mentioned. As to the results, no substantial changes were observed among learners' responses except one item regarding the difficulty of language learning. In fact, learners' responses to item 4 were doubled from $26.8 \%$ in time 1 to $54.5 \%$ in time 2 in the sense that passing a reading course at university appeared to have made them believe that learning English is difficult. It seems that learners' requirements regarding learning English was not fulfilled by the reading course or may be the teacher that their focus might be on the role of grammar and vocabularies during the term causing changes in learners' initial beliefs and considering English as a difficult language at the end of the term. In fact, this is due to the teaching reading system of Iranian high schools arming students with translations of the text rather than teaching reading comprehension proved by Mehrpour (2004) in which she realized that teaching reading in Iran is done without focusing on reading comprehension achieved by reading strategies taught by teachers for the purpose of comprehending reading texts.

In fact, it seems that the methodology adopted by a reading course (or general English course) at universities in Iran may be similar to Grammar Translation Method in which the focus is much more on grammar and vocabulary that is in contrast with today's accepted methodology focusing on communicative aspects of teaching.

\section{Conclusion}

The current study investigated changes in Iranian university students' beliefs about language learning applying quantitative methodology with the administration of BALLI questionnaire. Students' beliefs did not significantly change except one highlighting point that over half of the participants considered English as a difficult language in comparison with the beginning of the term that only more than one fourth of the Students thought that English is difficult to learn.

It seems that the course learners took during the term did not help them change their simplistic or unrealistic beliefs about grammar and vocabulary and moving toward somewhat new aspects of learning and teaching, such as communicative language learning or teaching 
may fulfill this requirement.

This study benefitted from quantitative methodology to probe changes in students' beliefs. In order to achieve precise and in-depth results regarding beliefs studies, more longitudinal and qualitative methodologies are needed to grasp the dynamic feature of beliefs.

\section{References}

Abelson, P. R. (1979). Differences between belief and knowledge systems. Cognitive Science, 3(4), 355-366.

Abelson, P. R. (1986). Beliefs are like possessions. Journal for the Theory of Social Behavior, 16(3), 223-250.

Bernat, E., \& Lioyd, R. (2007). Exploring the gender effect on EFL learners' beliefs about language learning. Australian Journal of Educational and Developmental Psychology, 7, 79-91.

Breen, M. P. (Ed.) (2001). Learner contributions to language learning: New directions in research. Harlow, Essex: Pearson Education Limited.

Cotteral, S. (1995). Readiness for autonomy: Investigating leaner beliefs. System, 23(2) 195-205.

Dornyei, Z., \& Ushioda, E. (2011). Teaching and researching motivation. Longman Pearson: Pearson Education Limited.

Horwitz, E. (1985). Using student beliefs about language learning and teaching in the foreign language methods course. Foreign Language Annals, 8(4), 333-340.

Horwitz, E. (1987). Surveying student beliefs about language learning. In A. Wenden and J. Rubin (Eds.), Learner strategies in language learning (pp.119-132). New York: Parentice Hall.

Horwitz, E. (1988). The beliefs about language learning of beginning university foreign language students. Modern Language Journal, 72(3), 283-294.

Horwitz, E. (1999). Cultural and situation influences on foreign language learners' beliefs about language learning: A review of BALLI studies. System, 27(4), 557-76.

Kalaja, P., \& Barcelos, A. M. F. (Eds.) (2003). Beliefs about SLA: New research approaches. Dordrecht: Kluwer Academic Press.

Kern, R. G. (1995). Students' and teachers' beliefs about language learning. Foreign Language Annals, 28(1), 71-92.

Mehrpoor, S. (2004). A causal model of factors affecting reading comprehension performance of Iranian learners of English as a foreign language. Unpublished Doctoral Dissertation. Shiraz University, Iran. 
Nespor, J. (1987). The role of beliefs in the practice of teaching. Journal of Curriculum Studies, 19(4), 317-328.

Pajares, M. F. (1992). Teacher's beliefs and educational research: cleaning up a messy construct. Review of Educational research, 62(3), 307-322.

Peng, J. (2011). Changes in language learning beliefs during a transition to tertiary study: The mediation of classroom affordances. System, 39(3), 314-324.

Rubin, J. (1975). What the "good language learner" can teach us. TESOL Quarterly, 9(1), 41-51.

Sakui, K., \& Gaies, S. J. (1999). Investigating Japanese learners' beliefs about language learning. System, 27(4), 473-492.

Siebert, L.L. (2003). Student and teacher beliefs about language learning. The ORTESOL Journal, 21, 7-39.

Thompson, A. (1992). Teachers' beliefs and conceptions: A synthesis of the research. In A. D. Grouws (Ed.), Handbook of research on mathematics learning and teaching (pp. 127-146). New York: Macmillan.

Wenden, A. (1987). How to be a successful learner: Insights and prescriptions from L2 learners. In A. Wenden and J. Rubin (Eds.), Learner strategies in language learning (pp.103-117). New York: Parentice Hall.

White, C. (1999). Expectations and emergent beliefs of self-instructed language learners. System, 27(4), 443-57.

White, C. (2008). Beliefs and good language learners. In Griffiths, C. (Ed.), Lessons from good language learners. Cambridge University Press, Cambridge, pp. 121-130.

\section{Appendix}

Appendix 1. Persian Version of BALLI Questionnaire

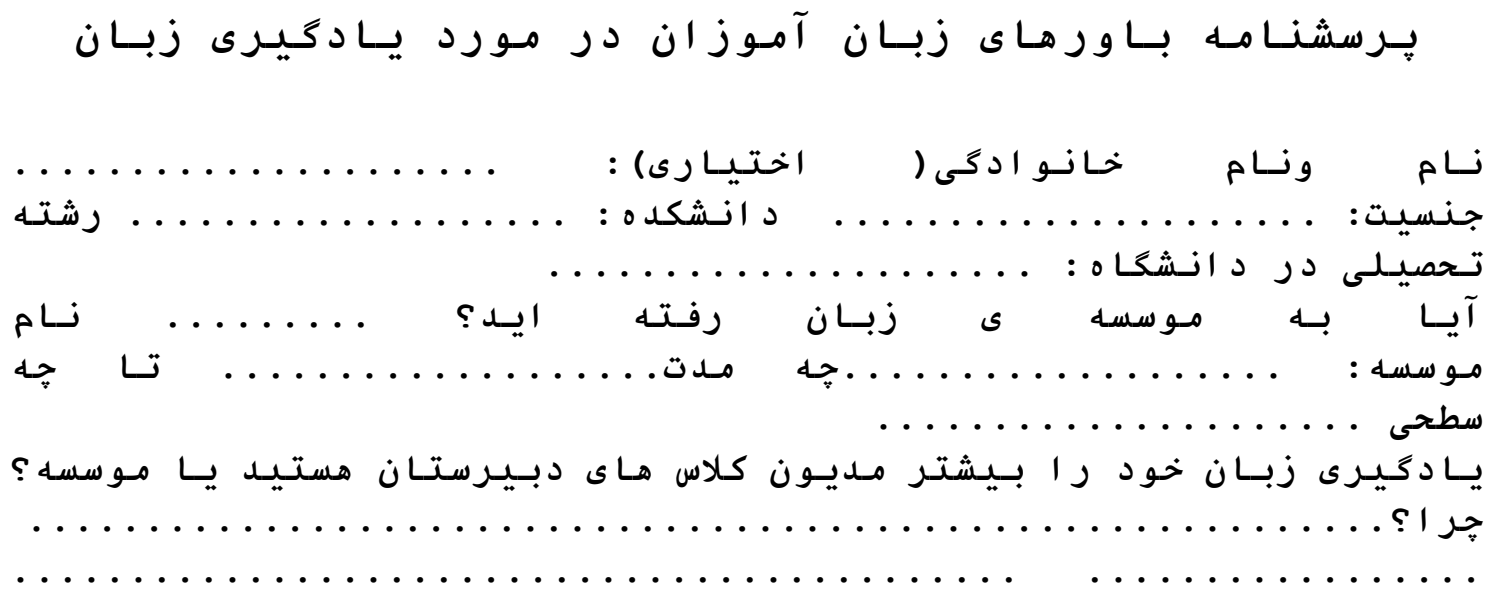




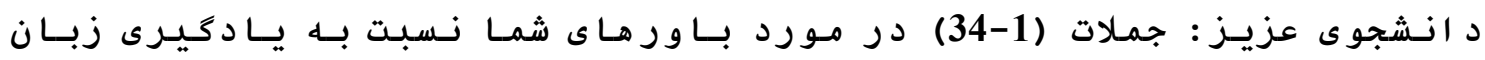

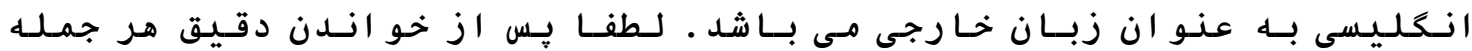

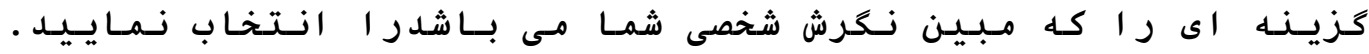

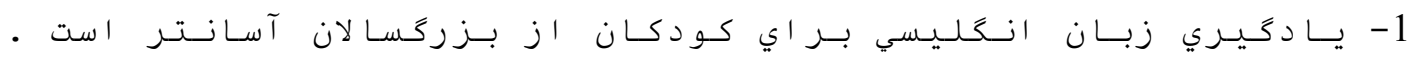

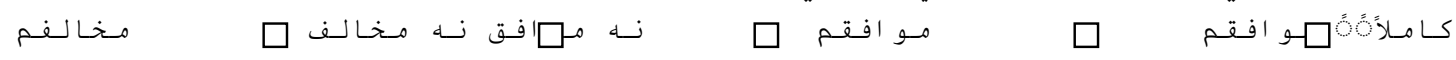

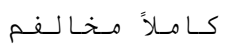

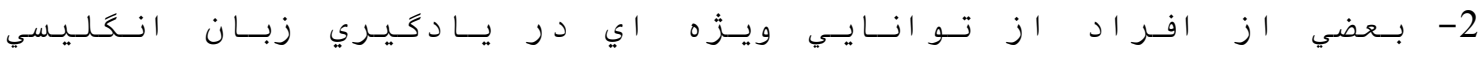

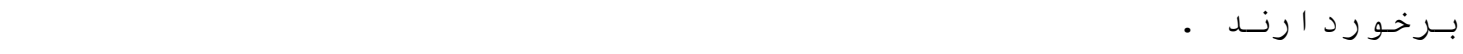

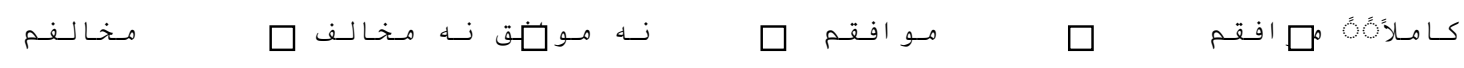
كـاملاً مـنالـن

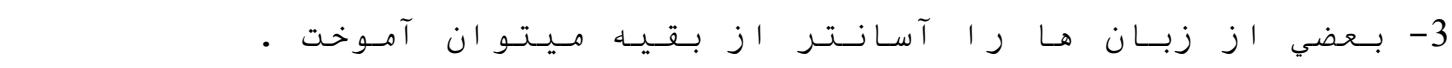

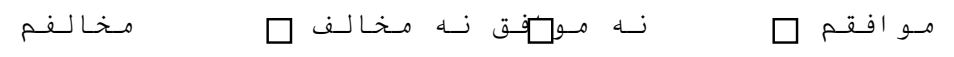

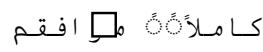

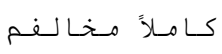

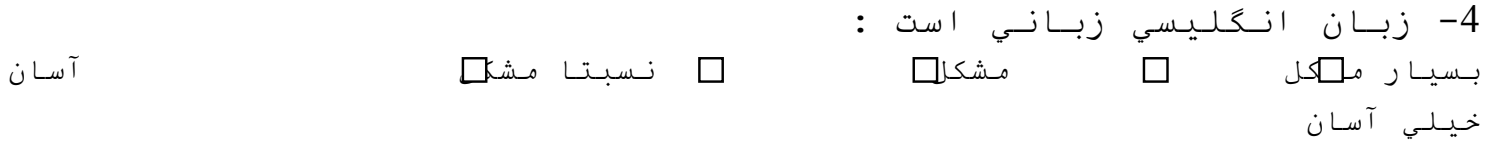

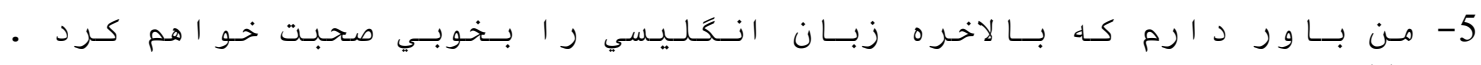
كسالأكَة

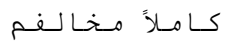

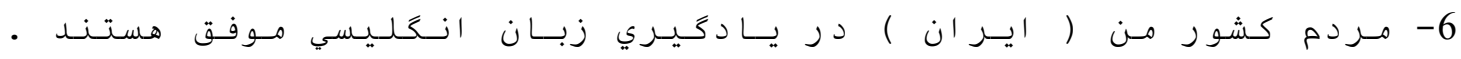

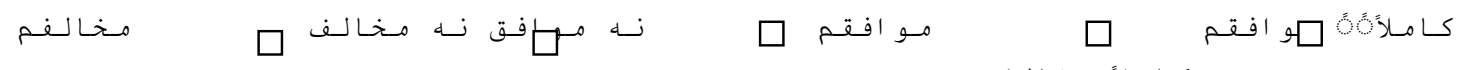

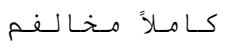

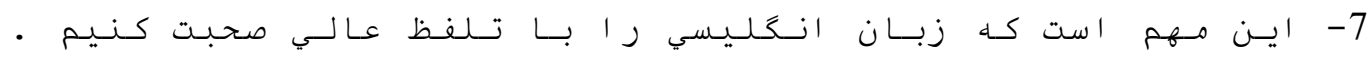

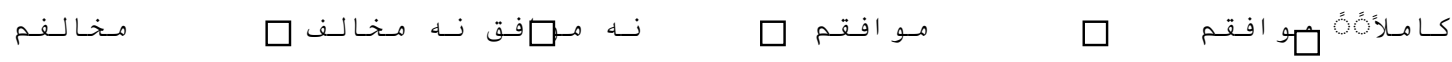

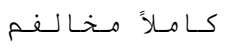

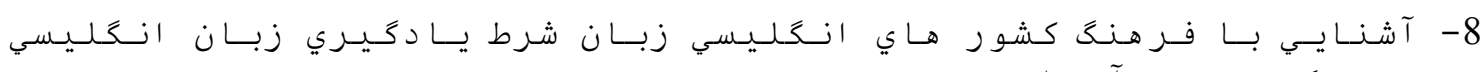

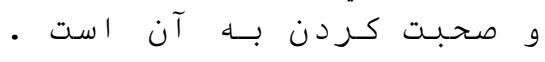

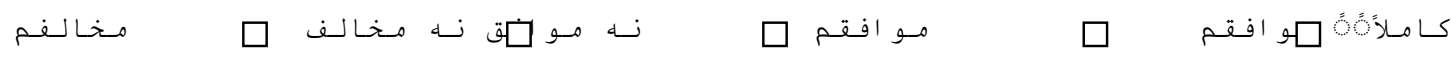

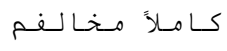

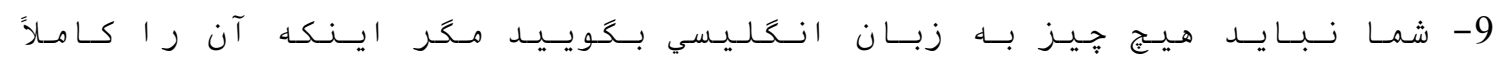

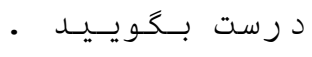
كسامسالوكة

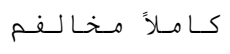

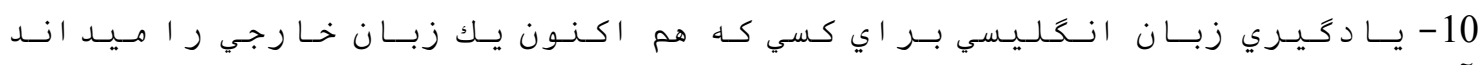

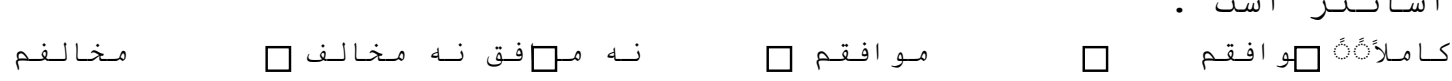
كامسلاً مـخالــن

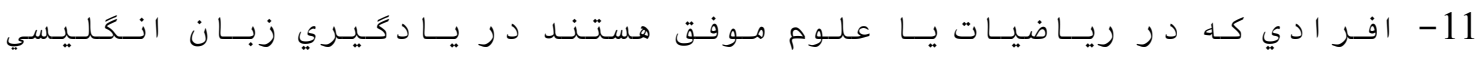

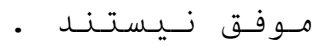




$$
\begin{aligned}
& \text { مخـا لـنم }
\end{aligned}
$$

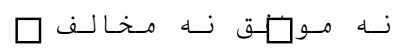

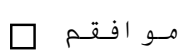

$$
\begin{aligned}
& \text { كـامـلاً مـخـا لـنـم }
\end{aligned}
$$

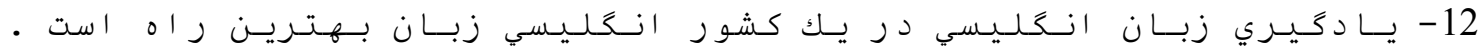

$$
\begin{aligned}
& \text { مـو افـقم } \\
& \text { كـامسلاً مـخـالــنـم }
\end{aligned}
$$

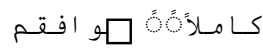

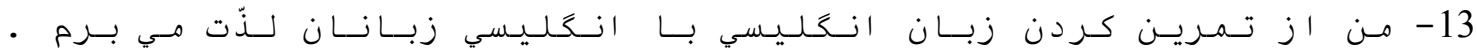

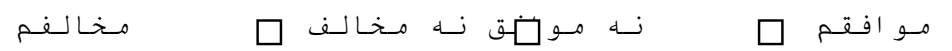

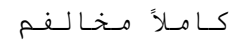

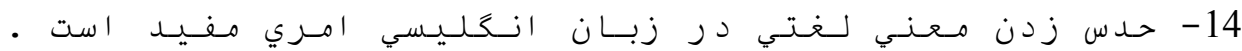

$$
\begin{aligned}
& \text { مـو افـتم } \\
& \text { كـامسلاً مسخـالـنـم }
\end{aligned}
$$

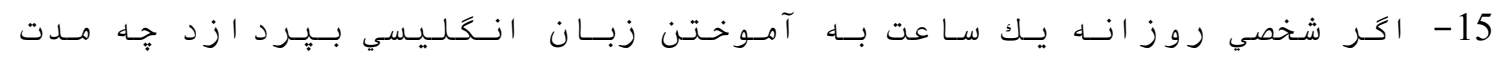

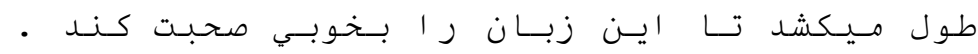

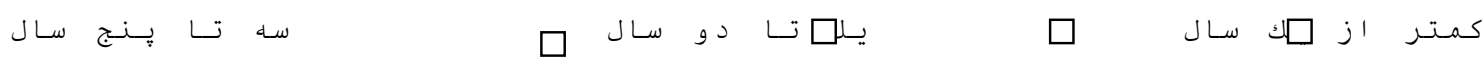

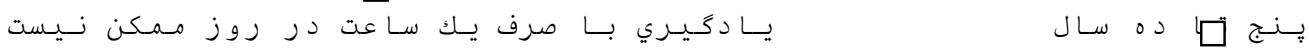

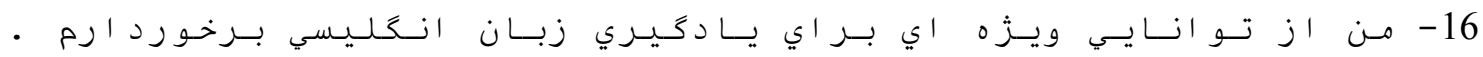

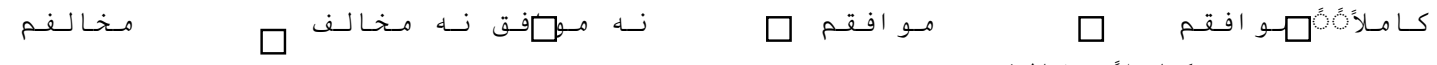

$$
\begin{aligned}
& \text { كـامـلاً مـخـا لـفنم }
\end{aligned}
$$

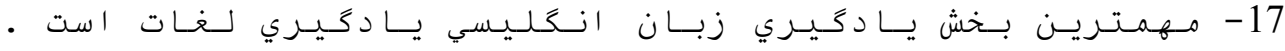

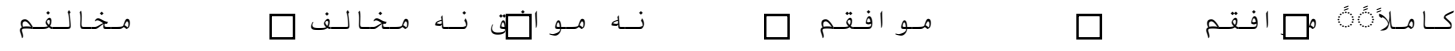

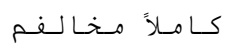

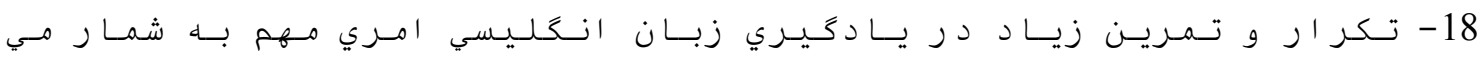

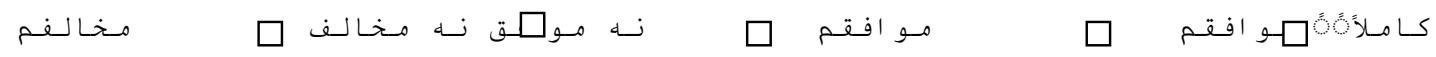

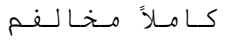

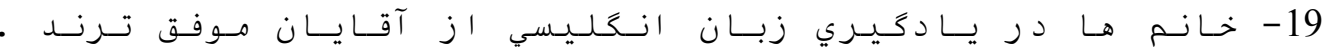

$$
\begin{aligned}
& \text { كسامسلأًكَ }
\end{aligned}
$$

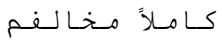

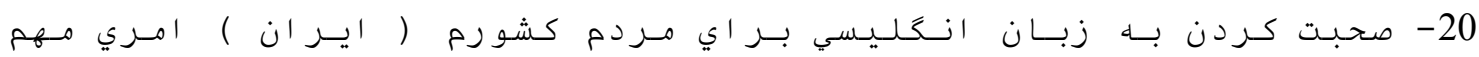

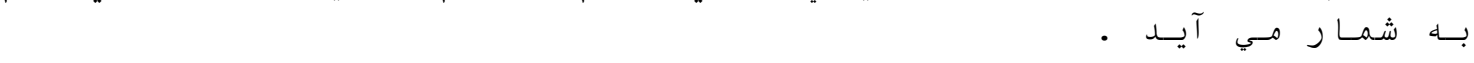

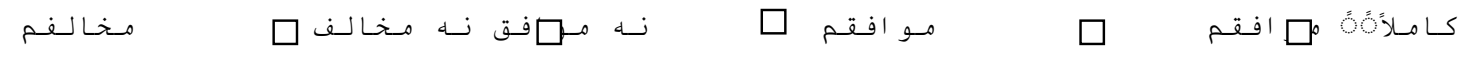

$$
\begin{aligned}
& \text { كامسلاً مـخـا لـفنم }
\end{aligned}
$$

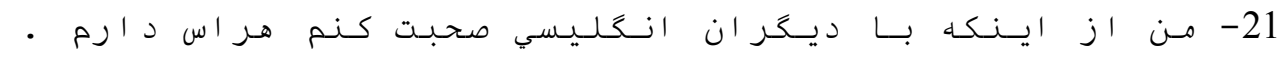

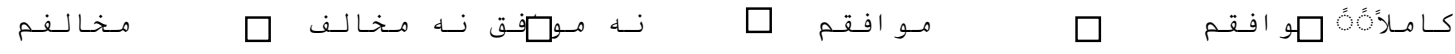

$$
\begin{aligned}
& \text { كـامـلاً مـخـا لـفنم }
\end{aligned}
$$

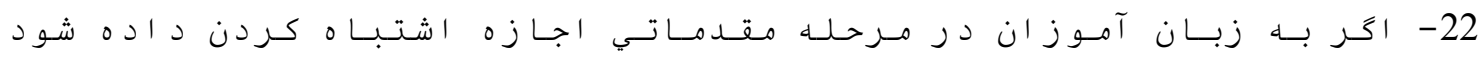

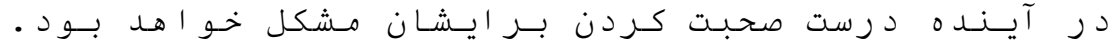

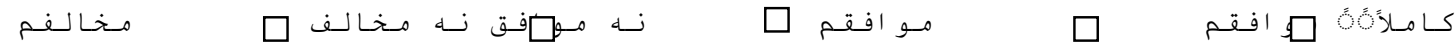

$$
\begin{aligned}
& \text { كـامسلاً مسخـالـنـم }
\end{aligned}
$$

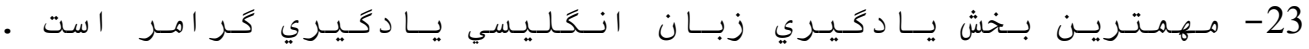

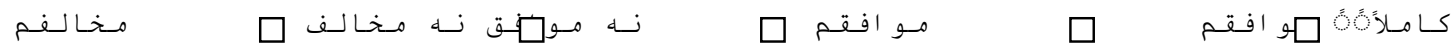

$$
\begin{aligned}
& \text { كـامسلاً مـخـالـنـم }
\end{aligned}
$$




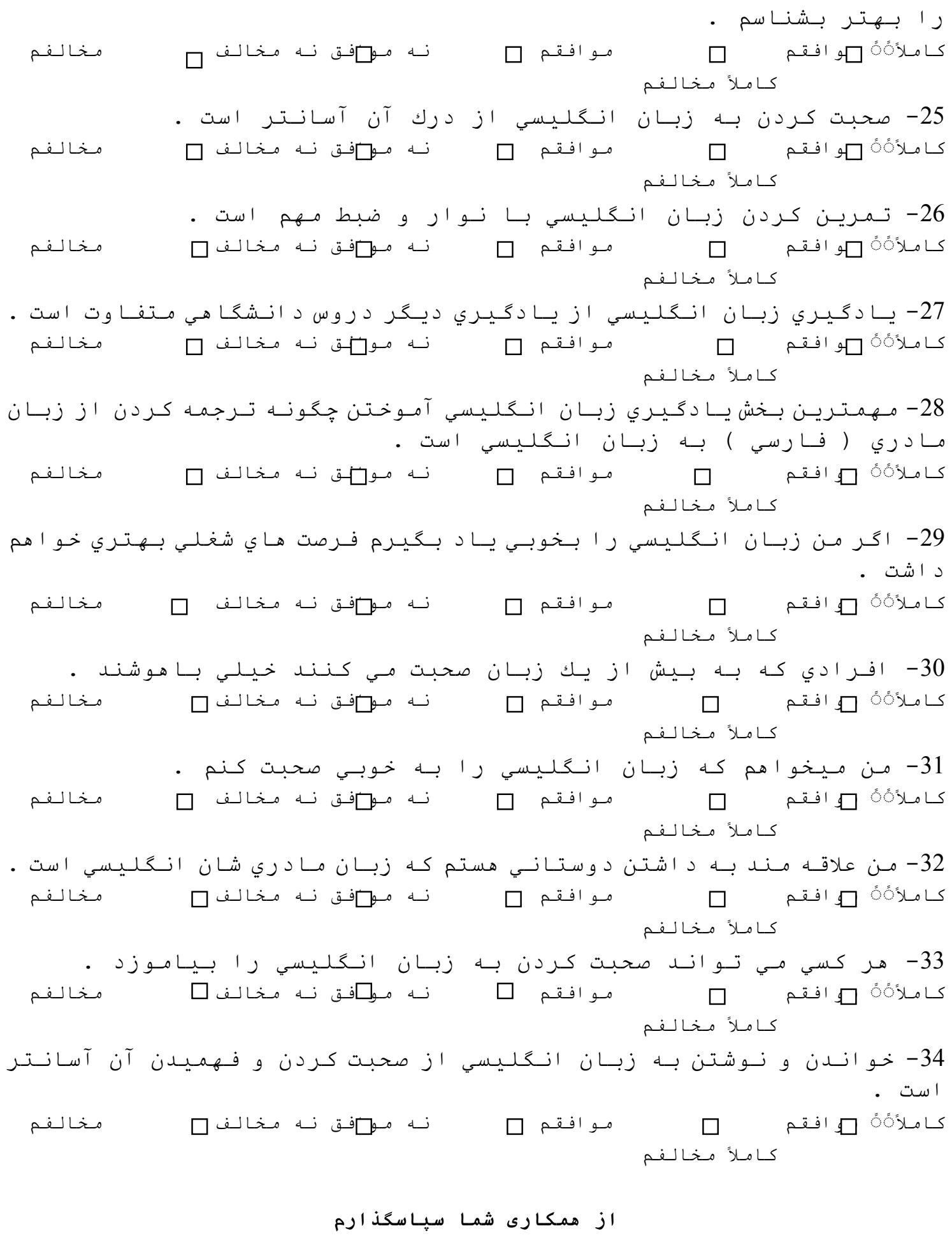




\section{Ml Macrothink \\ International Journal of English Language Education \\ ISSN $2325-0887$ 2015, Vol. 3, No. 1}

\section{Copyright Disclaimer}

Copyright for this article is retained by the author(s), with first publication rights granted to the journal.

This is an open-access article distributed under the terms and conditions of the Creative Commons Attribution license (http://creativecommons.org/licenses/by/3.0/). 